\title{
WHY AND HOW CENTRAL EUROPE'S LARGEST LOGISTICS COMPLEX DEVELOPED ON A BROWNFIELD SITE
}

Robert Krzysztofik, Iwona Kantor-Pietraga, Tomasz Spórna,

Weronika Dragan, Tomasz Szymonowicz

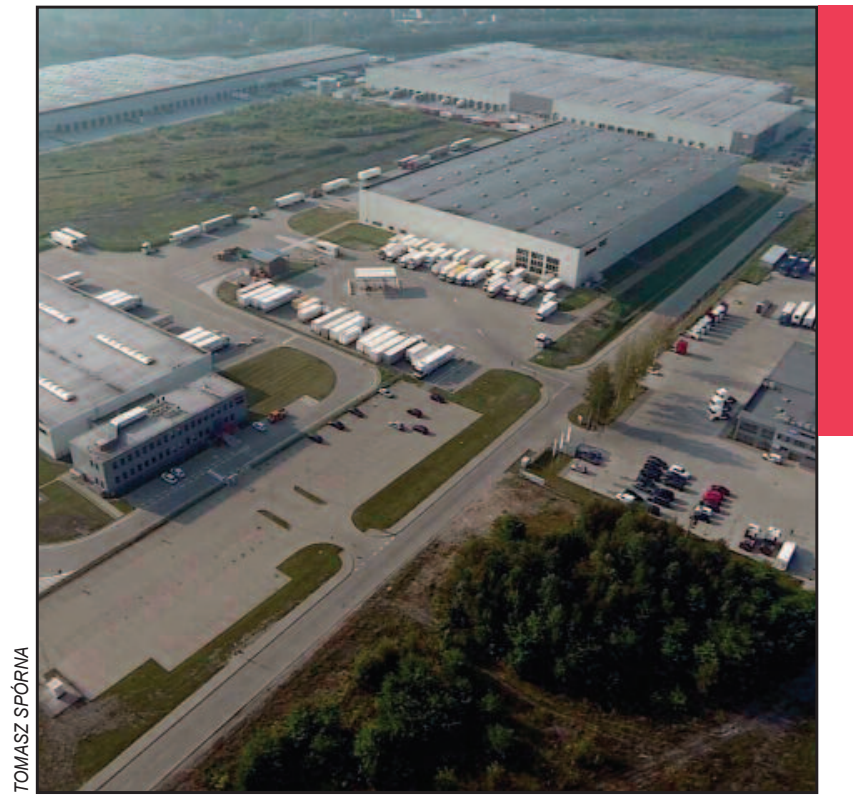

Sosnowiec - Amazon Fulfillment Center under construction (2017). The biggest logistics facility in the largest logistics complex on a brownfield site in Europe. 
DOI: https://doi.org/10.3986/AGS.7085

UDC: $911.375: 711.553(438)$

COBISS: 1.01

Robert Krzysztofik $^{1}$, Iwona Kantor-Pietraga ${ }^{1}$, Tomasz Spórna ${ }^{1}$, Weronika Dragan ${ }^{1}$, Tomasz Szymonowicz ${ }^{2}$

\section{Why and how central Europe's largest logistics complex developed on a brownfield site}

ABSTRACT: The aim of the article is to explain the dependence on key factors and development path in the expansion process of the largest Central European logistics complex situated on postmining brownfield. Here, a highly original example is the city of Sosnowiec in the Katowice conurbation (Poland). In the article, the development of this complex and its model of spatial diffusion, with an indication of both facilitating and restricting aspects of its further expansion is discussed. The following issues are also brought to light: spatial location, urban policy, transport accessibility and local labour market. In the article, the development of this complex is discussed according to model of spatial diffusion.

KEY WORDS: logistics complex, brownfields, urban polycentricity, facility location, Poland

\section{Zakaj in kako je potekal razvoj največjega srednjeevropskega logističnega kompleksa na degradiranem zemljišču}

POVZETEK: Namen članka je pojasniti odvisnost od ključnih dejavnikov in razvojno pot širitve največjega srednjeevropskega logističnega kompleksa na nekdanjem rudarskem zemljišču v poljskem mestu Sosnoviec v somestju Katovic. V članku avtorji obravnavajo razvoj navedenega kompleksa in model njegove prostorske razpršenosti, pri čemer predstavijo tudi vidike, ki podpirajo ali omejujejo njegovo nadaljnjo širitev. Poleg tega proučujejo naslednja vprašanja: lokacijo v prostoru, urbanistično politiko, prometno dostopnost in lokalni trg dela. Gradnjo kompleksa obravnavajo na podlagi modela prostorske razpršenosti.

KLJUČNE BESEDE: logistični kompleks, degradirana zemljišča, urbana policentričnost, lokacija storitve, Poljska

This paper was submitted for publication on November $10^{\text {th }}, 2018$.

Uredništvo je prejelo prispevek 10. novembra 2018.

\footnotetext{
${ }^{1}$ University of Silesia in Katowice, Institute of Social and Economic Geography and Spatial Management, Sosnowiec, Poland robert.krzysztofik@us.edu.pl (https://orcid.org/0000-0002-1433-0866), iwona.kantor-pietraga@us.edu.pl (https://orcid.org/0000-0003-2067-5438), tomasz.sporna@us.edu.pl (https://orcid.org/0000-0002-1099-7196), weronika.dragan@us.edu.pl (https://orcid.org/0000-0003-1531-2464)

${ }^{2}$ Municipal Office Sosnowiec, Department of Urban Development and Marketing, Sosnowiec, Poland t.szymonowicz@um.sosnowiec.pl
} 


\section{Introduction}

The growing role of logistics in the European and global economies is among the key attributes of modern globalisation. One of the results of this phenomenon is the growing number of logistics centres and their complexes in both developed and developing countries (De Ligt and Wever 1998; Hesse 2004; 2008; SkowronGrabowska 2009; Dablanc and Ross 2012; van den Heuvel et al. 2013; Walker and Manson 2014; Sakai, Kawamura and Hyodo 2015; Verhetsel et al. 2015; Straka and Wyrwich 2015; Aljohani and Thompson 2016). Undoubtedly, the post-socialist countries of Central Europe can be classified to the latter group. In this region, the development of logistics based on vehicle transport has been characterised by factors already identified in highly developed countries: deindustrialisation; spatial centralisation of stockholding adopted by manufacturers and retailers to achieve cost savings in their supply chains or rapidly rising land prices and increasing traffic congestion in urban areas (Allen, Browne and Cherrett 2012; Kraft 2012; Szołtysek 2016). One should also note the strong regional contrast of wages in this sector between East-Central and Western Europe, the great surplus of jobseekers in this sector compared to offers of employment and a strong rise in GDP in the mentioned countries (Roudná 2011; Jurásková and Macurová 2013; Grondys and Dragolea 2016) However, the most important argument pertains here to the deficit of cutting-edge logistics centres that would meet modern freight requirements. At that time, the logistics centres were obsolete in terms of infrastructure and usually situated in the city centres or heavily built-up areas (Haywood 2001; O'Connor and Parsons 2001; Strauss-Wieder 2010; Burdzik et al. 2013; Cui, Dodson and Hall 2015). Currently large logistics complexes develop both in accordance with the logistics sprawl and with the logistics anti-sprawl model (Aljohani and Thompson 2016; Dablanc, Ogilvie and Goodchild 2014; Krzysztofik, Kantor-Pietraga and Spórna 2019). A facilitating factor in both models, meanwhile, is the availability of large derelict areas that offer space for locating even several dozen facilities. However, the availability of brownfields in urban cores is not the only condition for development of large logistics complexes. The article aims to explain the complicated origins and unique development path of the largest logistics complex in Central and Eastern Europe located on a post-mining brownfield. This goal is important because research on such large logistics complexes is a research gap in the literature. Furthermore, the case of the «Bór « logistics zone in Sosnowiec in Poland presented in the article is unique due to its location within a former sandpit.

\section{Methods}

\subsection{Study area}

The Bór logistics complex is situated in southern Poland in a convenient location at the intersection of major communication routes of Poland and Central and Eastern Europe, i.e., motorways A1 and A4, and S1 (Figure 1). In the vicinity, there is also an international airport (Katowice Airport). The travel from Krakow and Ostrava to the logistics site takes 1 hour, whereas the travel time from Wrocław is 2 hours (Figure 1).

The specificity of this area also manifests in its previous usage. Until the end of the $20^{\text {th }}$ century it served as an industrial area (filling sand mining), whereas from the beginning of the $21^{\text {st }}$ century, it has been a place of dynamic development of the largest logistics area on brownfield land in Central Europe, complemented with other service and productions functions substantially related to transport (HGV servicing, car body production) (Figure 1).

\subsection{Data collection}

The studies on the development of »Bór « logistics complex were based on three sources. The first, concerning data of Sosnowiec City Council and companies engaged in the development of this area allowed construction dates of each facility to be determined with regard to the exact month and year. This pertained also to outward extension of the already existing facility. Moreover, information on the area of construction plots and facilities themselves were also collected. Regarding the subject of the article, the analysis also covered all planning and strategic documents pertaining to the analysed area with particular focus on the Master plan for Sosnowiec (2016). In order to obtain a full picture of the changes that are taking place and to make an attempt to develop future projections, the authors also interviewed 12 the key figures operating in this area (i.e., the local authorities, Panattoni, Goodman, NGO). 
The article uses two main research methods. First, desk research focused on analyzing facts and processes related to logistics development in the region (see subchapter 3.2). The second group of methods consisted of 12 interviews with the key stakeholders (representatives of municipal authorities, logistics companies, the Katowice Special Economic Zone and NGOs), since certain flows of information between individual entities operating in the analysed area, both direct and indirect, formal and informal, also proved to be significant. Two interviews were conducted as a telephone conversation (kind of CATI method), while the others were - face to face. All of them had a free-form review.

The use of desk research analysis as well as a interview (soft method) was aimed at confirming the correctness of treating the studied phenomenon in terms of diffusion of innovation. The model of spatial diffusion distinguishes 4 stages of diffusion of a new type of socio-economic feature or phenomenon and 5 groups of adopters of diffusion (see in brackets): penetration (innovators, early adopters), expansion (early majority), consolidation (late majority), full saturation (laggards) (Sanders ed. 2007; Rogers 2003. Because the number of facilities that have been established or may still be established in this area is less than 30, we refrained from using a rigid percentage range to define the boundaries between individual stages. We only adopted guidelines for the penetration stage - the innovator group, and the boundary of around 50\% of all facilities between the expansion (early majority) and consolidation (late majority) stage.

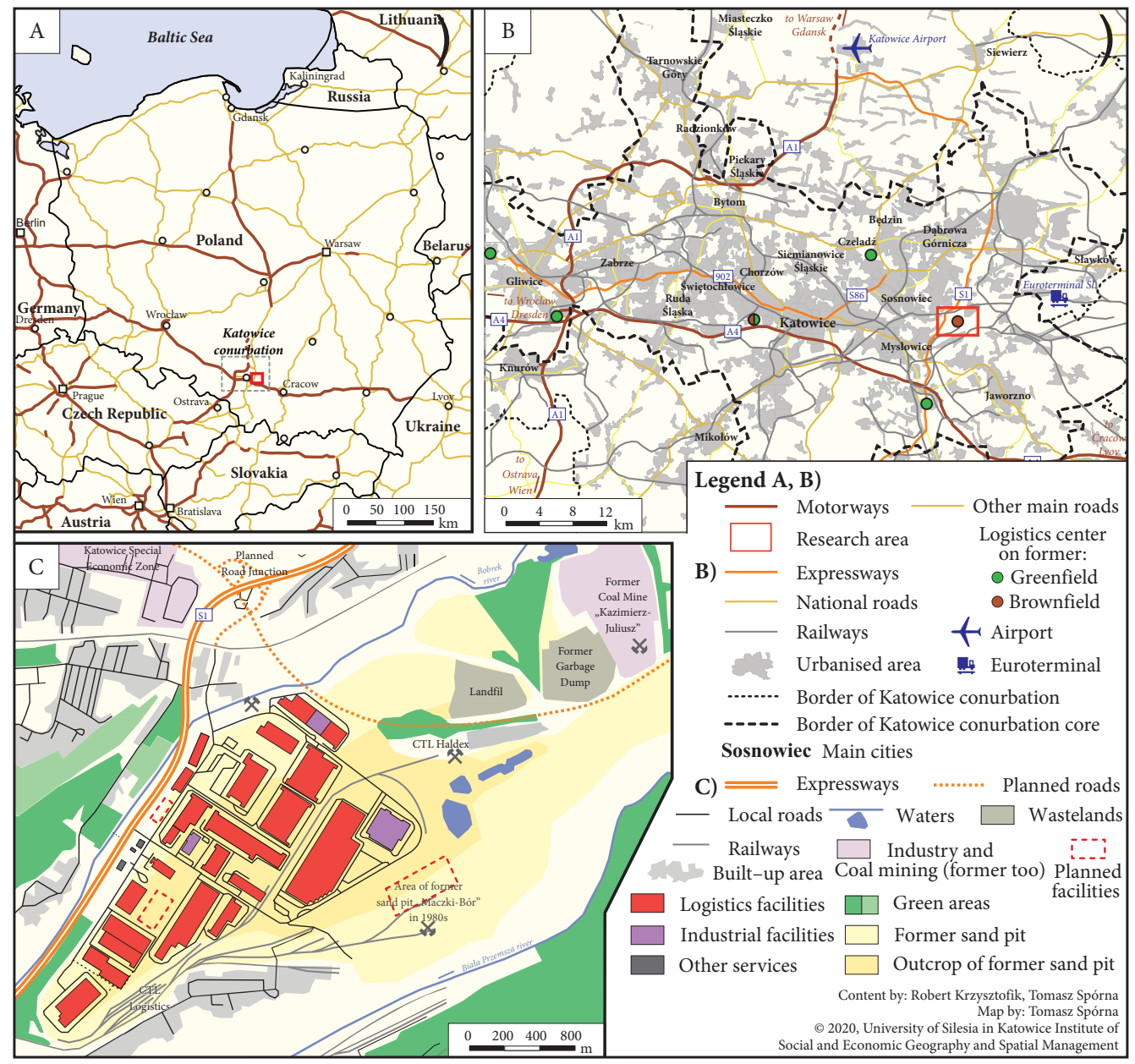

Figure 1: Study area. A) Location of the study area in (entral and Eastern Europe; B) Katowice conurbation; C) local scale (the city of Sosnowiec) 


\section{Results}

\subsection{Pre-logistics stage of development}

The development of the Bór logistics complex in Sosnowiec has an exceptionally atypical background. This exceptional nature stems not only from the fact that it was founded on a brownfield site but also because only 15-20 years earlier, the area was located as much as 30 metres lower than in the present day. This location was related to the existence of one of the few larger sandpits in southern Poland. On the eastern boundaries of the Katowice conurbation (the Upper Silesian Industrial Region), sand was excavated on a total area of over 20 square kilometres (Dulias 2010). Of these largest sandpits, the smallest was »Maczki-Bór « filling stone quarry (FSQ) in Sosnowiec (Figure 1). The sandpit was divided into two exploitation areas: Bór Wschód (East) and Bór Zachód (West). This logistics complex is situated at present within the former Bór Zachód (West) exploitation area.

\subsection{Stimulators and destimulators of development for the Sosnowiec logistics complex}

It was no accident the largest logistics complex in Central and Eastern Europe developed in a former sandpit. An analysis of the chart in Figure 2 demonstrates that around 2010, positive effects of many factors conducive to development accumulated. They had a trans-regional nature (development of expressways and airports in southern Poland, decrease in greenfields, expansion of large logistics companies and increase in demand for modern logistics facilities). However, the success of the area in question was determined by a combination of several causes with a decidedly local nature (providing a very large, $2 \mathrm{~km}^{2}$ brownfield for the investment, strong pro-investment policy of the city and the company administrating the brownfield, very good accessibility that was competitive compared to post-coalmining brownfields, high unemployment rate, strong social acceptance of new companies and diminishing possibilities for location of logistics centres on brownfields) (see Szołtysek 2016; Krzysztofik, Kantor-Pietraga and Spórna 2013; Krzysztofik et al. 2019). The accumulation of the above drivers caused a dynamic development of logistics functions, which

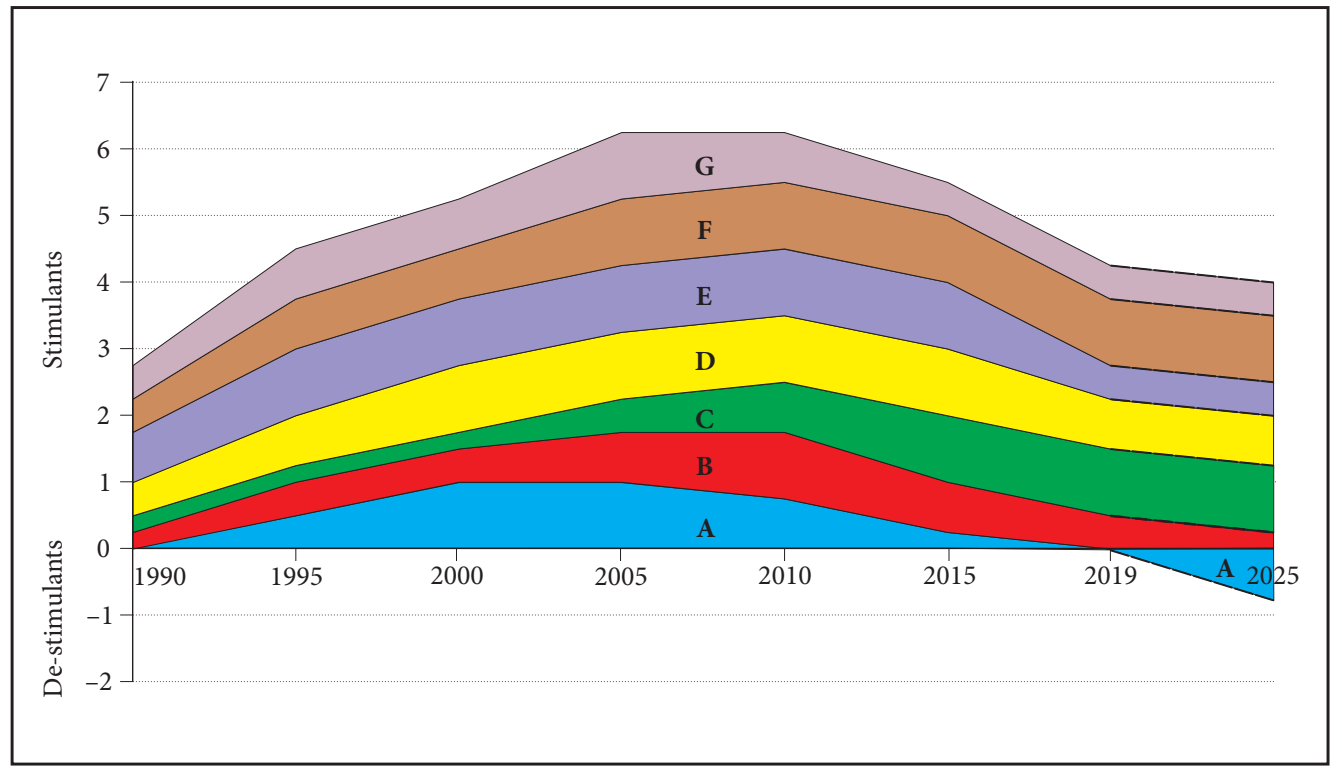

Figure 2: Emergence of the biggest logistics complex on a postmining brownfield site in Central and Eastern Europe. Explanations: A - labour market; $B$ - accessibility of brownfield (considered); C - national system of expressways; D - local policy; E - acceptance of local community; F- expansion of foreign capital; $\mathrm{G}$ - regional system of expressways and air cargo. 
to some extent surprised even the local authorities. From another perspective, it bears mentioning that the key investor in this area - Panattoni - did not decide to balance its activities on brownfield sites compared to those performed on greenfield sites on a broader scale in Poland until 2016. Though it had already pursued such investments earlier, it was not until 2017 that well-localised brownfields were recognised as not only a means for balancing greenfields but in many cases as the only option.

Full development of the former sandpit is also accompanied by changes that only several years ago could have slowed or even stopped the process under discussion. The most painful of them is the change on the labour market: a noticeable lack of workers, caused by rapid depopulation. In the years 2000-2019, Sosnowiec lost around 50,000 inhabitants (a fall from 235,000 to 185,000). Furthermore, social opposition is on the rise, focused on criticism of such a high density of trucks and road traffic problems in districts neighbouring logistics complexes. Not insignificant is also the change in urban policy: from the stage of »investment euphoria « still visible in the years 2015-2017, to the stage of "financially beneficial approval«.

\subsection{Diffusion model in the logistics site development}

The first investor (innovator) did not appear at the site until 2008. It was a branch of the German company Salzgitter Mannesmann, who erected steel product warehouses. For over 5 years their facility stood "alone « surrounded by the re-cultivated sandpit (Figure 3). On the one hand, the said facility was a symbol of attempts to reuse this area for business purposes, which were extensive though ineffective for a long time. On the other, it symbolised the investor's struggle with all the restrictions mentioned in the previous subchapter. When referring this investment to the concept of the diffusion of innovations, one ought to consider it a stage of penetration (Sanders 2007).

The breakthrough in the development of the discussed logistics and service complex discussed in the article took place in the years 2012-2015. At that time, CTL Logistics sold a considerable part of its property to large developer companies Goodman, Panattoni and Raben (early adopters). They all decided to create their logistics parks there. This factor had an unquestionable impact on the synergy of the advances development of this area (cf. Verhetsel et al. 2015). The said synergy was additionally reinforced by the factor of a short geographic distance between the logistics facilities and end delivery sites (cf. Allen et al. 2012; Cidell 2010). It should be noted that this period was linked to a clear growth of the role of individual pro-investment drivers in the logistics sector (Figure 2). This growth was visible both with respect to internal factors (labour market, urban policy, new local road investments and airport expansion), and supralocal factors (FDI inflow to Poland, extension of the road network in south Poland, shrinkage of greenfields, greater interest of global businesses in the Katowice region).

In the 2012-2015 period, investments in the former sandpit site were made by: Raben - two facilities, Jeronimo Martins - distribution centre, Panattoni Park I, II, Goodman - 3 facilities (Figure 3). In terms of infrastructure, this was complemented by the construction of 3 new internal roads within the complex areas. Moreover, several minor infrastructural investments were made within the area. In the view of the spatial diffusion model it should be noted that the discussed phenomenon resulted in the formation (expansion and early majority) of logistics facilities on various sites of the said area.

The new development stage, i.e., consolidation (late majority), occurred in the years 2016-2017. In that period, new facilities were founded by Panattoni Park III, Goodman (Eurocash) and DBK The total area of facilities commissioned throughout this stage is over $200,000 \mathrm{~m}^{2}$. This period consolidated 3 key cores of development - northern (dominated by Panattoni Parks), central (dominated by Panattoni Parks and other companies) and southern (dominated by Goodman Park and Raben).

Until the beginning of 2018, were commissioned: an ambulance assembly plant of the Polish company Auto Form, Swedish HAGS and also two Panattoni Parks V and VI. The last (2019) investor in the discussed area is developer - 7R. In mid-2019, it was building 3 BTS logistics centres directly next to the S1 expressway.

By the end of 2019, the total surface of logistics facilities (»under the roof «) in the analysed area will exceed around $550,000 \mathrm{~m}^{2}$ (Figure 4), and will total approximately $1,000,000 \mathrm{~m}^{2}$ including accompanying infrastructure (parking lots, docks, roads, greenery and others). CTL Logistics is also preparing a new investment site near the Amazon facility. Total area of all facilities (manufacturing, other services) in this area is more than $580,000 \mathrm{~m}^{2}$ (Figure 4). 
The next stage in the development of the discussed investment area began in 2018 and will probably last until 2020-2022. Regarding the model of spatial diffusion of innovation, this stage is referred to as the stage of full saturation (Sanders 2007).

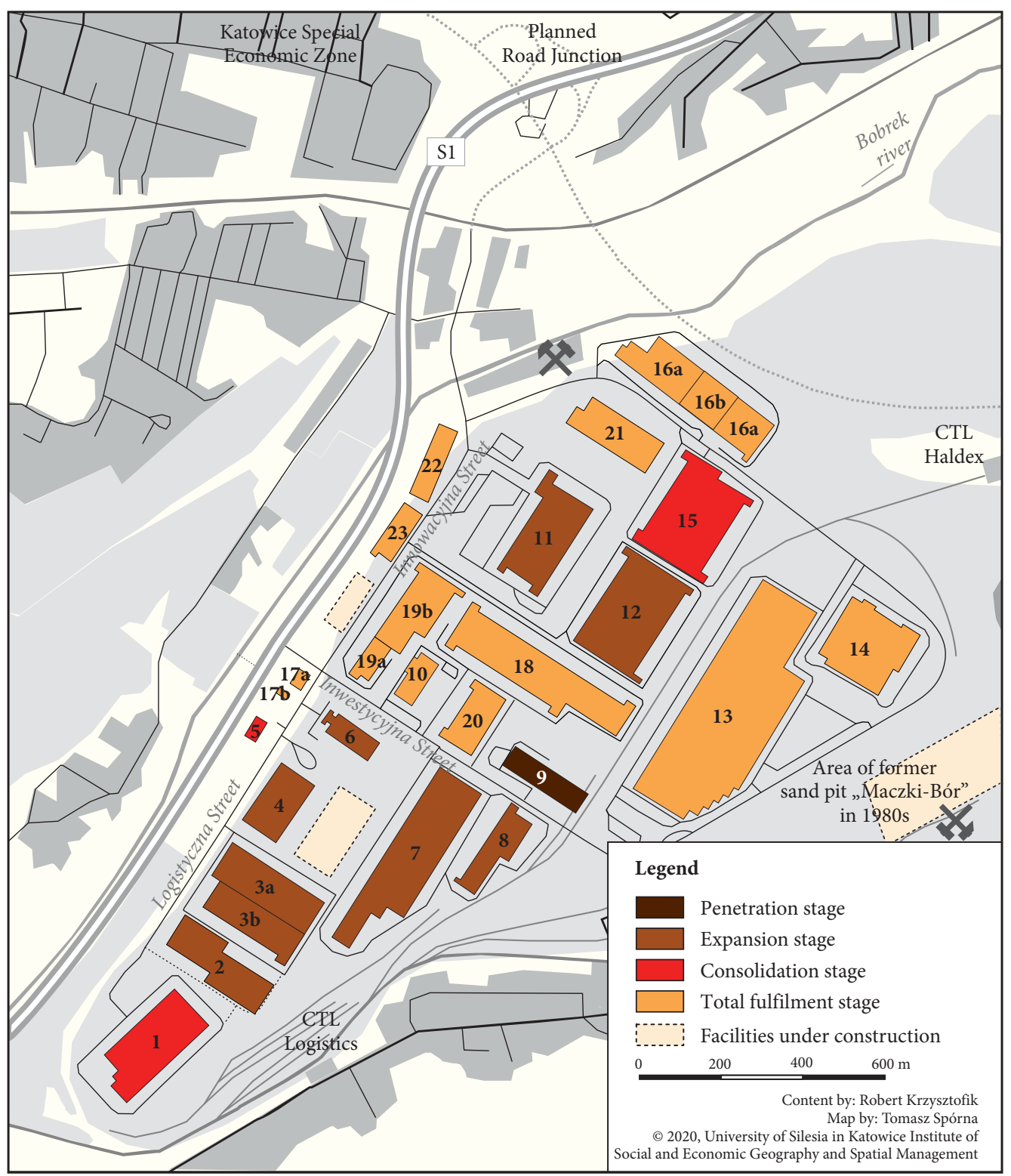

Figure 3: Logistics site development stages (Sosnowiec, Poland - former sand pit). Markings: I - penetration stage; II - expansion stage; III - consolidation stage; IV - full saturation stage; Numbers: 1 - Goodman Poland (Eurocash); 2 - Goodman Poland (DSV Solutions); 3a,[b - expansion] Goodman Poland (Inter Cars); 4 - Raben II; 5 - DBK Truck Center; 6 - Raben I; 7 - Panattoni Park II A; 8 - Pannatoni Park II B; 9 - Salzgitter Mannesmann Stahlhandel; 10 - Auto Form; 11 - Jeromino Martins; 12 - Pannatoni Park I (A,B); 13 - Amazon Fulfillment Poland; 14 - Hags; 15 - Panattoni Park III; 16a - Panattoni Park IV (DSV Solutions; Corenso); 16b - Amazon (manufacturing); 17a - Orlen Oil Station; 17b - Mc Donalds \&; 18 - Panattoni Park V A; 19 - Panattoni Park V B; 20 - Panattoni Park V C; 21 - Panattoni Park VI; 22 - 7R (InPost); 23 - 7R. 
Number of investments

Area

(cumulated)

$\left(1,000 \mathrm{~m}^{2}\right.$, cumulated)

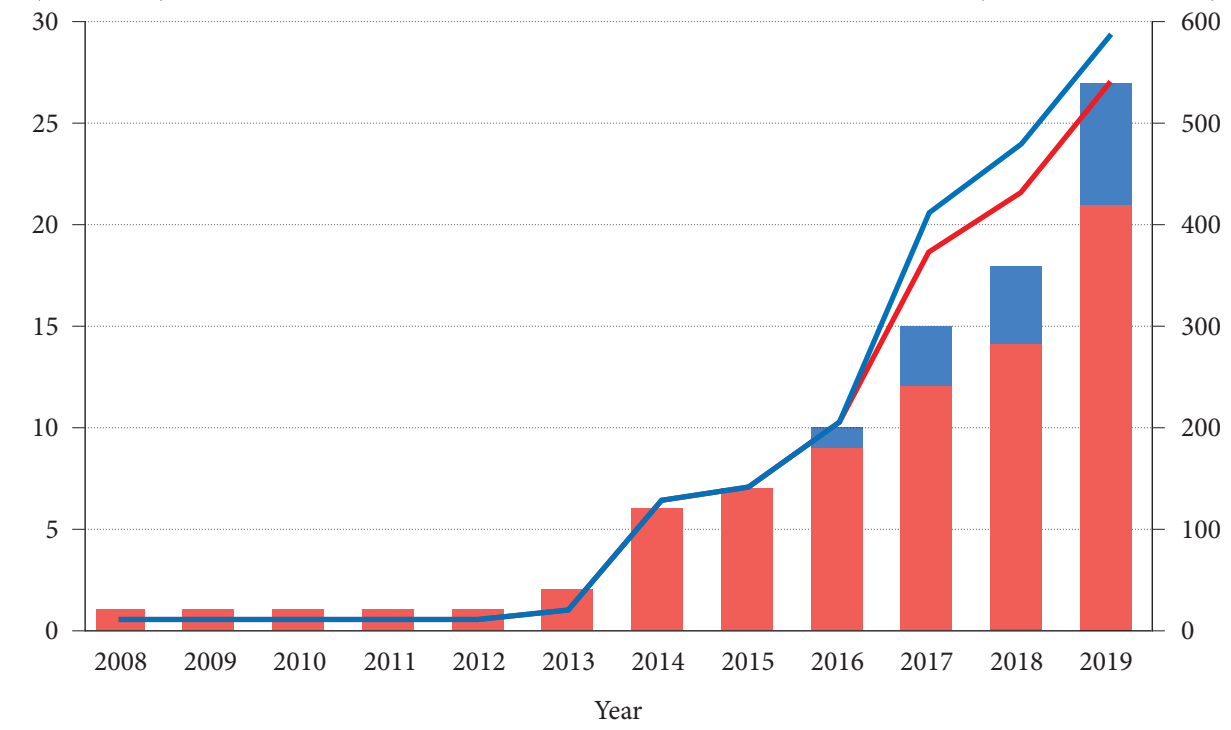

- Area of all investments (1,000 $\mathrm{m}^{2}$ cumulated)

Number of all investments (cumulated)

- Area of logistics investments $\left(1,000 \mathrm{~m}^{2}\right.$, cumulated)

Number of logistics investments (cumulated)

Figure 4: Dynamics of investments inside of the logistics complex »Bór« in Sosnowiec, Poland

\section{Discussion}

The development of economic complexes, such as the one discussed in the article, can be considered in terms of both diffusion and synergy. In the analyzed case, due to specific backstage development (no cooperation, we are building because we have already built here, and not because we are counting on measurable benefits from the existence of other objects', the existence of competing companies) it was assumed that the diffusion attribute prevails. In this case, a large investment area was a location niche for many independent investments of different companies that at the same time built their facilities in other parts of the region (cf. Sheffi 2012; Krzysztofik et al. 2019).

Given proper conditions, i.e., the polycentric nature, low land prices in core cities, the specific course of expressways, such a niche could be located within the agglomeration core and not in the suburbs, contrary to the popular belief (Davoudi 2003; Heitz and Dablanc 2015). Moreover, relatively low land prices are also significant in this matter. Another important argument supporting the location of mega centres is the absence of the need to invest in micro urban consolidation centres (MUCC) and urban logistics spaces (ULS), which are subcentres that facilitate good deliveries in high-density urban monocentric metropolitan areas (cf. Dablanc, Ogilvie and Goodchild 2014; Janjevic and Ndiaye 2014; Woudsma, Jakubicek and Dablanc 2015). Regarding logistics investments, this fact is to some extent contradictory to the sprawl processes that have been observed worldwide (Krzysztofik et al. 2019).

A no less important problem is the relationship between logistics centre expansion and brownfield redevelopment. This relationship is in keeping with the policy of sustainable development and reindustrialisation of brownfields well-known in Eastern and Central Europe (cf. e.g. Wirth, Černič Mali and Fischer 2012; Frantal et al. 2013; Perić 2016). In the case of this particular logistics complex there is another important question: 
why did it develop on the site of a defunct sandpit, and not one of the post-coalmining brownfields that are very numerous in this region? When answering this question, attention should be drawn to the following facts. First, active policy of the defunct sandpit's owner is by far more expansive than the actions of the state company - SRK (Company for Restructuring of Coalmining) that controls most post-coalmining brownfields in the Katowice region. A model in which two expansive private entities cooperate is far more effective than the more difficult relationship between logistics company and state mining restructuring company. Projects in which a third partner, the Katowice Special Economic Zone or city authorities appear, are the exception.

In the investigation of the phenomenon of the investment area in question, it should also be noted that the area developed was a very large, compact site of a defunct open-cast, and the numerous underground coal mines of the region have smaller surfaces. Furthermore, post-coalmining brownfields in the city of Sosnowiec are not always very accessible from the main expressway.

Also very significant was the periodisation of development, underlined in the article. Since the end of the 1990s, the best locations on post-coalmining brownfields were redeveloped by industrial investments. At that time, the logistics sector was more focused on suburban greenfields (Krzysztofik et al. 2019). Logistics companies interested in good accessibility of large urban cores were thus limited to brownfields. As P. Kociołek, environmental director at Panattoni, stated in an interview (December 2017), »brownfields are a natural stage of expansion of this sector in cities".

Taking the above into account, also the possibilities of establishing such complexes in the future should be discussed. Especially as there exist more post-sandmining sites that could potentially become new areas for investment. However, due to their distance from the conurbation core and the emerging strong social need for turning defunct sandpits into leisure areas, the analysed case of Sosnowiec will probably be unique. Dispersion of logistics investments among complexes that are more numerous but smaller than the Sosnowiec one is also brought about by the most important destimulant for the development of logistics: lack of employees caused by depopulation of the Katowice region. Some large logistics companies reacted rapidly, creating their own bus lines to bring in employees from up to 50-60 km away. The trend of locating new logistics centres in greater dispersion is confirmed among others by a new phenomenon observed in the Katowice conurbation. It involves building logistics centres in intraurban greenfields and in the place of demolished 19th century industrial plants that are slightly less accessible in terms of transport. In both cases (postindustrial brownfields and intraurban greenfields) the key factor is low prices and lack of the legal and ownership problems so common for many greenfields in suburban areas. In such cases it is also relatively easier to find employees.

\section{Conclusion}

The founding of the logistics complex on the former sandpit site in Sosnowiec is quite an unusual phenomenon. The trend aims to locate giant investment clusters of this sort primarily towards the suburban area situated at a distance from core cities of agglomeration, which are in general greenfield-type investments. Although the discussed investment area was not formed in the very city centre, it lies in an urban area within the administrative boundaries of a 2-million urban area core. This example is therefore one of the most significant examples of the phenomenon of anti-sprawl in logistics (Krzysztofik et al. 2019). The unique nature of this area stems also from the fact that it is the first case of this type and size in Europe to be founded on a former sandpit site.

The article also indicates that the development of large clusters of logistics centres on brownfield sites, as pointed out in the article, will have more advantageous conditions in polycentric and post-industrial agglomerations. However, the most advantageous conditions would come together with overlapping polycentric and post-industrial attributes. Because new niches for location of logistics facilities exist, also within post-coalmining brownfields, further development of the logistics anti-sprawl phenomenon should be expected in the region under study, although it will probably not concern former sandpits. The existence of a large defunct sandpit in Sosnowiec thus had, in addition to several other more egalitarian drivers, a particular significance in the process of development of the largest logistics complex on a brownfield in Europe.

The article also emphasizes that the development of this type of logistics complexes can be considered in terms of diffusion. Regardless of the noticeable aspect of the synergy. The size of the analyzed area allows even competing companies whose free development is based on the idea - "I build where others build, but I develop business regardless of neighbors". 
ACKNOWLEDGEMENT: We would like to thanks management of CTL Logistics, Panattoni Europe, Raben Logistics Polska sp. z.o.o. and Goodman Poland for all information that deepened explanations presented in paper. Our special thanks for Piotr Kociołek - Environmental Director - Panattoni Europe and Anita Petrykowska - Marketing and Communication Director - Panattoni-Poland.

\section{References}

Aljohani, K., Thompson, R. G. 2016: Impacts of logistics sprawl on the urban environment and logistics: Taxonomy and review of literature. Journal of Transport Geography 57. DOI: https://doi.org/10.1016/ j.jtrangeo.2016.08.009

Allen, J., Browne, M., Cherrett, T. 2012: Investigating relationships between road freight transport, facility location, logistics management and urban form. Journal of Transport Geography 24. DOI: https:/doi.org/ 10.1016/j.jtrangeo.2012.06.010

Burdzik, R., Macioszek, E., Sierpiński, G., Warczek, J. 2013: Analiza rozbudowy i lokalizacji centrów i obiektów logistycznych w aglomeracji śląskiej. Zeszyty Naukowe Politechniki Śląskiej. Seria Transport 78.

Cidell, J. 2010: Concentration and decentralization: the new geography of freight distribution in US metropolitan areas. Journal of Transport Geography 18. DOI: https:/doi.org/10.1016/j.jtrangeo.2009.06.017

Cui, J., Dodson, J., Hall, P. V. 2015: Planning for urban freight transport: An overview. Transport Reviews 35-5. DOI: http://dx.doi.org/10.1080/01441647.2015.1038666

Dablanc, L., Ogilvie, S., Goodchild, A. 2014: Logistics sprawl: differential warehousing development patterns in Los Angeles, California, and Seattle, Washington. Transportation Research Record. Journal of the Transportation Research Board 1-2410. DOI: https://doi.org/10.3141/2410-12

Dablanc, L., Ross, C. 2012: Atlanta: a mega logistics center in the Piedmont Atlantic Megaregion (PAM). Journal of Transport Geography 24. DOI: https://doi.org/10.1016/j.jtrangeo.2012.05.001

Davoudi, S. 2003: Polycentricity in European spatial planning: from an analytical tool to a normative agenda. European Planning Studies 6-4. DOI: https://doi.org/10.1080/0965431032000146169

De Ligt, T., Wever, E. 1998: European Distribution Centres: Location Patterns. Tijdschrift voor Economische en Sociale Geografie 89-2. DOI: https://doi.org/10.1111/1467-9663.00021

Dulias, R. 2010: Landscape planning in areas of sand extraction in the Silesian Upland, Poland. Landscape and Urban Planning 95-3. DOI: https://doi.org/10.1016/j.landurbplan.2009.12.006

Frantál, B., Kunc, J., Nováková, E., Klusáček, P., Martinát, S., Osman, R. 2013: Location matters! Exploring brownfields regeneration in a spatial context (A case study of the South Moravian Region, Czech Republic). Moravian Geographical Reports 21-2. DOI: https://doi.org/10.2478/mgr-2013-0007

Grondys, K., Dragolea, L. 2016: Logistics attractiveness of Poland in relation to logistics centres and global competition. Polish Journal of Management Studies 14-1. DOI: https://doi.org/10.17512/pjms.2016.14.1.08

Haywood, R. 2001: Rail-freight growth and the land use planning system. Town Planning Review 72-4. DOI: https://doi.org/10.3828/tpr.2001.72.4.445

Heitz, A., Dablanc, L. 2015: Logistics spatial patterns in Paris: the rise of the Paris Basin as a logistics megaregion. Transportation Research Record: Journal of the Transportation Research Board 1-2477. DOI: https://doi.org/10.3141/2477-09

Hesse, M. 2004: Land for logistics: locational dynamics, real estate markets and political regulation of regional distribution complexes. Tijdschrift voor economische en sociale geografie 95-2. DOI: http://dx.doi.org/ 10.1111/j.0040-747X.2004.t01-1-00298.x

Hesse, M. 2008: The City as a Terminal: The Urban Context of Logistics and Freight Transport. Ashgate.

Janjevic, M., Ndiaye, A. B. 2014: Development and application of a transferability framework for microconsolidation schemes in urban freight transport. Procedia - Social and Behavioral Sciences 125. DOI: https://doi.org/10.1016/j.sbspro.2014.01.1474

Jurásková, K., Macurová, P. 2013: The study of logistic parks in the Czech Republic. Journal of Applied Economic Sciences 25-3.

Kraft, S. 2012: A transport classification of settlement centres in the Czech Republic using cluster analysis. Moravian Geographical Reports 20-3. 
Krzysztofik, R., Kantor-Pietraga, I., Spórna, T. 2013: A Dynamic approach to the Typology of Functional Derelict Areas (Sosnowiec, Poland). Moravian Geographical Reports 21-2. DOI: https://doi.org/10.2478/ mgr-2013-0008

Krzysztofik, R., Kantor-Pietraga, I., Spórna, T., Dragan, W., Mihaylov, V. 2019: Beyond »logistics sprawl« and »logistics anti-sprawl«. Case of the Katowice region, Poland, European Planning Studies 27-8. DOI: https://doi.org/10.1080/09654313.2019.1598940

Master plan of Sosnowiec, 2016: Studium Uwarunkowań i Kierunków Przestrzennego Zagospodarowania Miasta Sosnowca. Sosnowiec.

O'Connor, K., Parsons, H. 2011: The impact of logistics activity on cities. State of Australian Cities National Conference Melbourne, Victoria, Australia.

Perić, A. 2016: Instititutional Cooperation in the Brownfield Regeneration Process: Experiences from Central and Eastern European Countries. European Spatial Reasearch and Policy 23-1. DOI: https://doi.org/ 10.1515/esrp-2016-0002

Rogers, E. M. 2003: Diffusion of innovations. New York.

Roudná, I. 2011: Prostorová lokalizace logistických center v České Republice. Ph.D. thesis, Univerzita Pardubice. Pardubice.

Sakai, T., Kawamura, K., Hyodo, T. 2015: Locational dynamics of logistics facilities: Evidence from Tokyo. Journal of Transport Geography 46. DOI: https://doi.org/10.1016/j.jtrangeo.2015.05.003

Sanders, L. (ed.) 2007: Models in spatial analysis. London.

Sheffi, Y. 2012: Logistics clusters: delivering value and driving growth. Cambridge.

Skowron-Grabowska, B. 2009: Place of Polish, Hungarian and Slovak Logistics Centers in Transport Systems. Advanced Logistic Systems 3.

Straka, M., Wyrwich, S. 2015: Funkcjonowanie centrów logistycznych w Polsce i Słowacji. Logistyka 2.

Strauss-Wieder, A. 2010: Warehousing and Distribution Center Context NJPTA. Brownfield Economic Redevelopment Project 2001.

Szołtysek, J. 2016: Logistyka miasta. Warszawa.

van den Heuvel, F. P., de Langen, P. W., van Donselaar, K. H., Fransoo, J. C. 2013: Spatial concentration and location dynamics in logistics: the case of a Dutch province. Journal of Transport Geography 28. DOI: https://doi.org/10.1016/j.jtrangeo.2012.10.001

Verhetsel, A., Kessels, R., Goos, P., Zijlstra, T., Blomme, N., Cant, J. 2015: Location of logistics companies: a stated preference study to disentangle the impact of accessibility. Journal of Transport Geography 42. DOI: https://doi.org/10.1016/j.jtrangeo.2014.12.002

Walker, G., Manson, A. 2014: Telematics, urban freight logistics and low carbon road networks. Journal of Transport Geography 37. DOI: https://doi.org/10.1016/j.jtrangeo.2014.04.006

Wirth, P., Černič Mali, B., Fischer, W. 2012: Problems and Potentials of Post-Mining Regions. Post-Mining Regions in Central Europe - Problems, Potentials, Possibilities. München.

Woudsma, C., Jakubicek, P., Dablanc, L. 2015: Logistics Sprawl in North America: Methodological Issues and a Case Study in Toronto. Transportation Research Procedia 12. DOI: https://doi.org/10.1016/ j.trpro.2016.02.081 